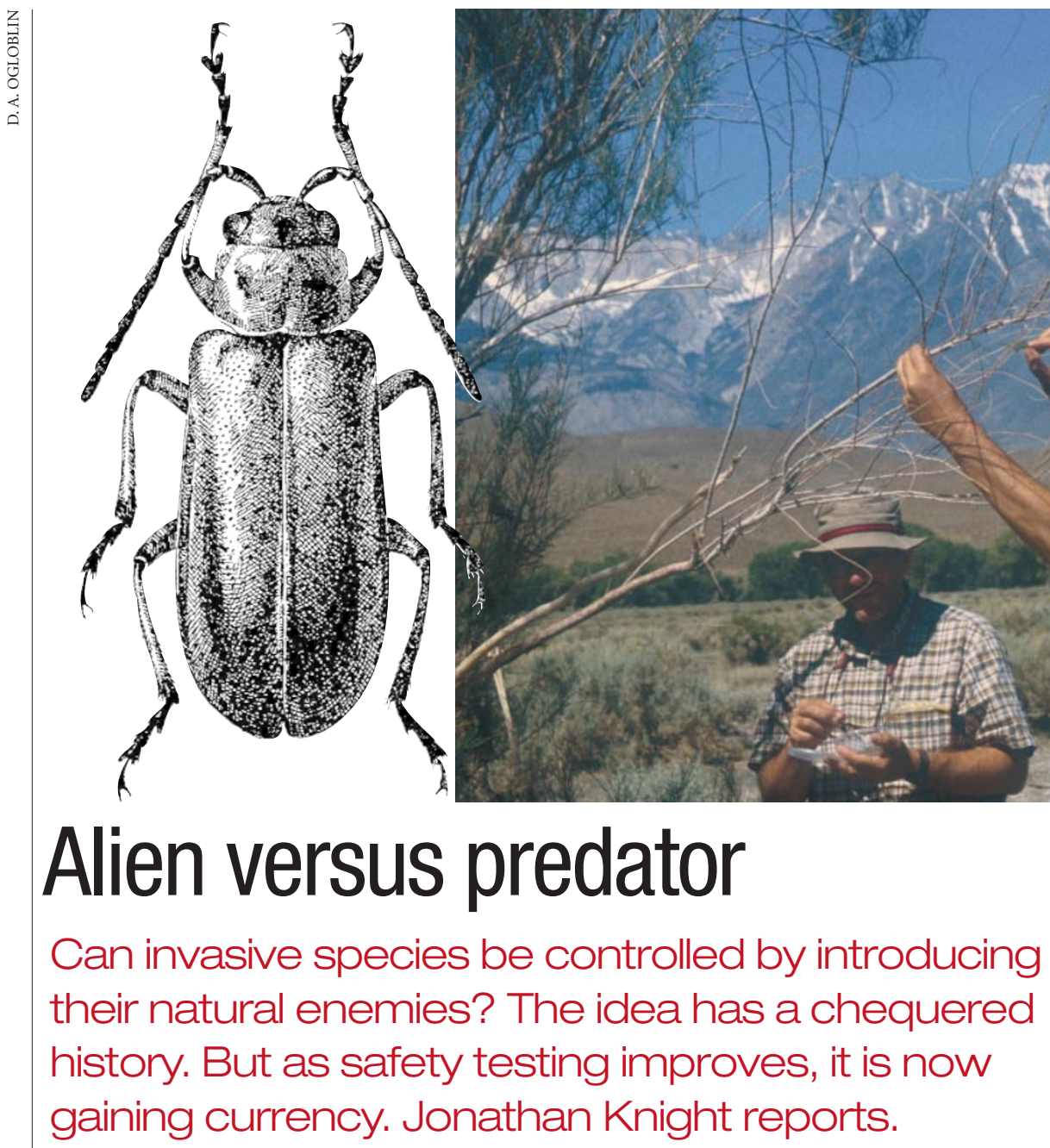

$\mathrm{T}$ hroughout the world, exotic aliens are wreaking havoc. From Japanese knotweed in the wetlands of Europe to Russian wheat aphids in the plains of North America, invasive species spread to new habitats by human activities are causing serious harm to ecosystems and agriculture. One estimate puts the annual cost at $\$ 137$ billion in the United States alone ${ }^{1}$.

Invading species often do well in their new environments because they lack the predators that kept them in check back home. So, for more than a century, people have tried dealing with problem exotics by importing more exotics to feed on them.

The results have been mixed - about one-third of species introduced to control exotic weeds have been judged a success ${ }^{2}$. The Australian experience illustrates the extremes. In a notable success, the cactus moth (Cactoblastis cactorum) was imported from Argentina in 1925 to deal with an infestation of prickly pear (Opuntia spp.). The moth reclaimed some 6.5 million hectares of rangeland for agriculture in just a few years without harming a single native Australian plant. But this must be set against infamous ecological disasters. In one example, cane toads (Bufo marinus) imported to northern
Queensland in 1935 showed little appetite for the sugar-cane beetles they were meant to control. Instead, they have munched their way through much of the region's unique wildlife.

Although critics still worry about the potential for things to go wrong, recent improvements in safety testing before release have begun to ease fears about biocontrol getting out of control. And in May, scientists with the Agricultural Research Service (ARS), the research arm of the US Department of Agriculture (USDA), released what is thought to be the most carefully tested and monitored biocontrol agent ever.

The ARS is deploying Chinese leaf beetle (Diorhabda elongata) against saltcedar trees (Tamarix spp.). These trees, native to Europe and the Middle East, now infest river banks throughout the western United States, where they are displacing native willow and cottonwood. Their deep roots draw up salt, raising topsoil salinity and killing undergrowth.

In theory, biological control is an elegant solution to an intractable problem. It is usually much more specific to the target than pesticides or herbicides, and if the control organism takes hold, it is self-perpetuating. But introduced organisms cannot be with-

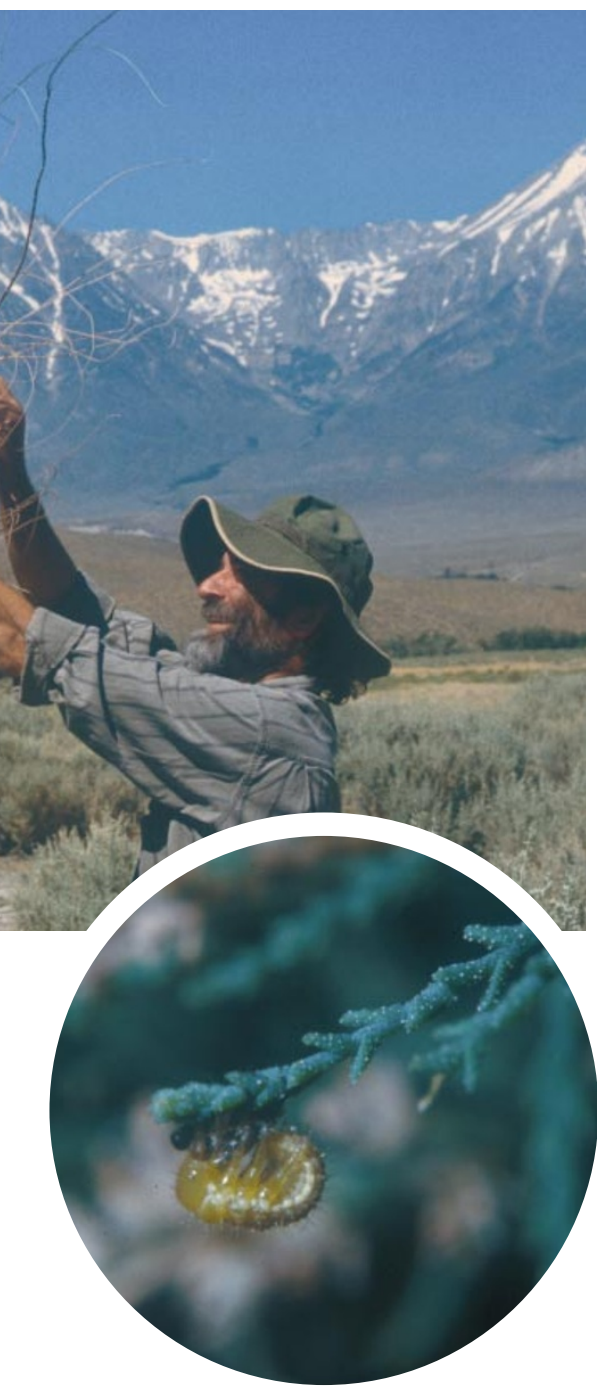

Beetlemania:

Tom Dudley (top, right) releases Diorhabda (top left) in California in an effort to combat saltcedar. The insect's larvae (inset) seem to feed almost exclusively on the trees.

drawn. Even if an exotic biocontrol agent has no damaging consequences at the initial site of release, its spread can create problems. After the cactus moth was introduced to Nevis in the Caribbean in 1957 to control prickly pears, it spread from island to island. Now it threatens rare native cacti in southern Florida. Ultimately, it could reach Mexico, where prickly pear is an economically important crop.

\section{Ground force}

Biological control of invasive species is gaining in popularity. Peter McEvoy, an entomologist at Oregon State University in Corvallis, found that the number of agents released to control invasive weeds in his state doubled to nearly 70 in the decade ending in 1997 (ref. 3 ). The trend is similar around the world ${ }^{4}$.

Traditionally, the prime motivation has been to protect agriculture, which has outweighed concern for native species. The Eurasian weevil (Rhinocyllus conicus), for 


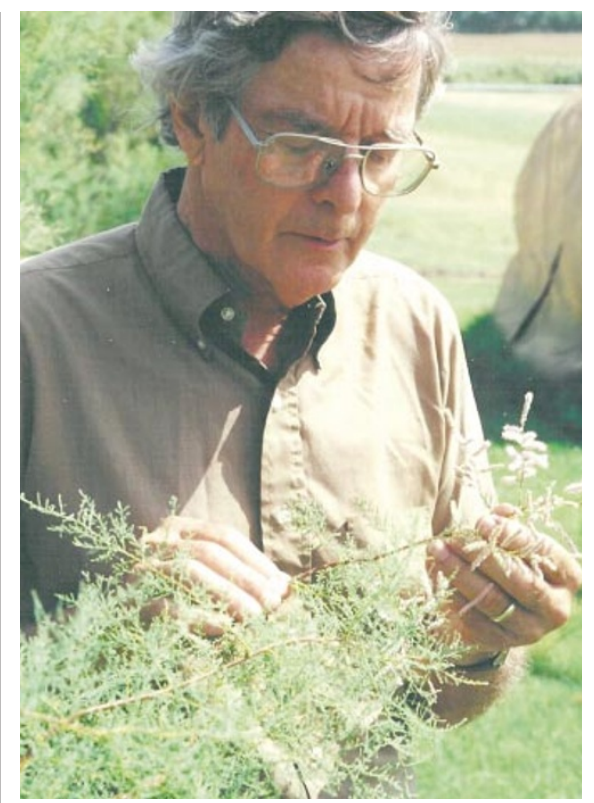

Low risk: Jack DeLoach believes Diorhabda's eating habits will make it safe to release.

instance, was released in the United States and Canada during the late 1960s to control introduced thistles that were overrunning grazing land, even though these invaders were growing beside native thistle species. In 1997, field biologists in Colorado and Nebraska found that the weevil was feeding on the seeds of seven native thistle species in national parks and nature reserves ${ }^{5}$.

But growing sensitivity to the need to protect native species has led to a tightening of the rules, says Tom Dudley, who works on biological control at the University of California, Berkeley. "If the thistle project were proposed right now, there is no way it would be approved," he says.

\section{One-track minds}

The key to safety in biological control is target specificity. The best targets are those that have no close relatives in the area they have invaded, and the best control agents are those that eat one thing only.

The saltcedar control programme scores well on both criteria. Prickly pears in Australia made a good target because they had no close relatives, and saltcedar is in a similar position in the western United States. Several species were imported in the nineteenth century as windbreaks and ornamentals. Two of them, Tamarix parviflora and T. ramosissima, are now causing serious ecological harm. Because they have no close relatives in North America, Jack DeLoach, a biologist at the ARS's station in Temple, Texas, was able to convince a federal regulatory board in the late 1980s that biological control would pose a low risk.

The USDA had started looking for suitable enemies to deploy against Tamarix in 1987. Two years later, DeLoach's team identified the Diorhabda leaf beetle, in western China, where it had been thwarting local attempts to grow saltcedar for erosion control by consuming its foliage. Over the past nine years, under conditions of tight quarantine in Temple, DeLoach and his colleagues have tested the beetle on more than 100 plants native to western North America. Diorhabda showed little appetite for any of them. "There is no case of anything being tested as carefully as this," says Dudley, who works on the saltcedar team. "We can never be $100 \%$ sure of no negative effects, but we are pretty darn sure at this point."

Researchers who have been critical of previous attempts at biological control agree that Diorhabda is probably safe to release. "In this one case I'm not too worried," says Daniel Simberloff, a specialist in the biology of invasive species at the University of Tennessee in Knoxville. "They have been very good about testing."

The saltcedar programme is also notable for its long-term follow-up plan. Past attempts at biological control have released different species in rapid succession with little subsequent study, in the hope that at least one would do the job. But in 1999, the ARS began requiring any new weed-control programme to develop a long-term management plan to measure its effectiveness - and, if necessary, to help replant with native species. Only after one agent is deemed inadequate will the next be brought in.

A long-term management plan is particularly relevant in the case of saltcedar. Trees take much longer to kill than herbaceous weeds, as they can survive several years of defoliation before they begin to die back. The saltcedar monitoring programme will also monitor the progress of the southwestern willow flycatcher (Empidonax traillii extimus). This endangered bird has taken to nesting in saltcedar in parts of Arizona, and conservationists are worried that killing the trees will leave it with nowhere to breed. The May releases of Diorhabda were made at least 200 kilometres from the bird's saltcedar nesting sites, and ARS researchers will be watching how quickly native willow and cottonwood replace any dead saltcedar. If the return of native species is too slow, the USDA and other agencies will consider planting trees to ensure that the birds have a place to nest.

Although ecological safety is now an issue in weed-control programmes, the application of similar standards to the biocontrol of invasive insect species has lagged behind. The USDA's Animal and Plant Health Inspection Service (APHIS) has been liberal in granting release permits, and it is a similar story around the world.

Fewer than 400 invertebrates and fungi have been released for weed control, anywhere in the world ${ }^{3}$. But some 5,000 organisms have been released worldwide in attempts to control exotic insects, according to a database compiled by $\mathrm{CAB}$ International, a non-profit organization based in
Wallingford, Oxfordshire, that promotes the development of sustainable agriculture.

Between 1986 and 1993, for example, APHIS released 29 insect enemies to attack the Russian wheat aphid (Diuraphis noxia), a serious problem for Midwestern farmers. None has been particularly effective, but at least one, the seven-spot ladybird (Coccinella septempunctata), now appears to be pushing out native ladybird species ${ }^{6}$.

\section{Food for thought}

In the United States, at least, rules introduced under the Plant Protection Act of July 2000 now require insect-control researchers to provide APHIS with a full Environmental Assessment before they are permitted to release predatory insects. The new rules have "certainly raised everyone's awareness and sensitivity", says Russell Messing, a biocontrol researcher at the University of Hawaii on Kauai.

If this increased sensitivity leads to insect-control programmes adopting the rigorous methods used in the saltcedar project, the chances of repeating the canetoad disaster should be greatly reduced. That would be welcome, as the threat posed by exotic species is growing all the time.

"Not doing anything is clearly a very negative process for the environment," says Ray Carruthers, who heads the ARS's Exotic and Invasive Weed Research Unit in Albany, California, which administers the saltcedar project. "We either sit here and watch it happen, or try to develop effective programmes that have minimal environmental risk."

Jonathan Knight writes for Nature from San Francisco.

1. Pimentel, D., Lach, L., Zuniga, R. \& Morrison, D. BioScience 50, 53-65 (2000)

2. Williamson, M. \& Fitter, A. Ecology 77, 1661-1666 (1996).

3. McEvoy, P. B. \& Coombs, E. M. Ecol. Appl. 9, 387-401 (1999).

4. Julien, M. H. \& Griffiths, M. W. (eds) Biological Control of

Weeds: A World Catalogue of Agents and their Target Weeds (CABI Publishing, Wallingford, UK, 1998).

5. Louda, S. M., Kendall, D., Connor, J. \& Simberloff, D. Science 277, 1088-1090 (1997).

6. Obrycki, J. in Nontarget Effects of Biological Control (eds Follett, P. A. \& Duan, J. J.) 31-44 (Elsevier, Dordrecht, the Netherlands, 2000).

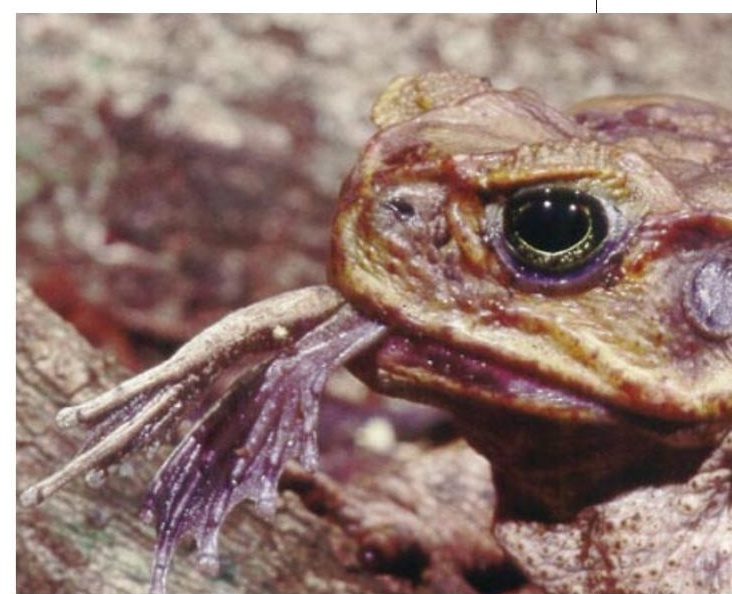

Toad haul: the cane toad eats almost anything except the beetles it was meant to control. 